\section{BENTUK PUTUSAN PENYELESAIAN SENGKETA BERDASARKAN MEDIASI ${ }^{1}$}

Oleh: Idris Talib ${ }^{2}$

\section{ABSTRAK}

Tujuan dilakukannya penelitian ini adalah untuk mengetahui bagaimana pengaturan hukum tentang penyelesaian sengketa secara mediasi dan bagaimana bentuk putusan penyelesaian sengketa secara mediasi. Berdasarkan penelitian hukum normatif disimpulkan bahwa 1. Bentuk penyelesaian sengketa menurut hukum terdiri atas penyelesaian sengketa melalui pengadilan (Legitasi), dan penyelesaian sengketa diluar pengadilan (non-legitasi). Sedangkan penyelesaian sengketa diluar pengadilan dibagi atas dua bagian besar yaitu melalui arbitrase, dan melalui alternatif penyelesaian sengketa yang meliputi cara-cara: Konsultasi, Negosiasi, Mediasi, Konsolidasi, dan penilaian ahli. 2. Mediasi adalah cara bermusyawarah dan bermufakat, untuk mencapai kesepakatan bagi para pihak bersengketa, melalui perantaraan seorang selaku mediator. Jika kata sepakat dicapai maka dibutuhkan penguatan dalam bentuk akta perdamaian sebagai putusan mediasi yang didaftarkan dan dikuatkan oleh Pengadilan Negeri. Tercapainya kesepakatan melalui mediasi, dengan sendirinya persengketaan selesai atau berakhir.

Kata kunci: mediasi, penyelesaian sengketa

\section{PENDAHULUAN}

\section{A. Latar Belakang Masalah}

Penyelesaian sengketa di luar pengadilan pada umumnya menggunakan cara-cara yang berbeda dengan penyelesaian sengketa melalui pengadilan, yakni digunakannya beberapa cara antara lainnya ialah negosiasi dan mediasi. Bentuk

\footnotetext{
${ }^{1}$ Artikel skripsi. Dosen pembimbing sk5ripsi: Dr. Merry E. Kalalo, SH, MH, Jeany Anita Kermite, $\mathrm{SH}, \mathrm{MH}$, Imelda $\mathrm{A}$. Tangkere, $\mathrm{SH}, \mathrm{MH}$.

${ }^{2}$ NIM: 090711468.
}

penyelesaian sengketa secara mediasi misalnya, juga telah diatur secara tersendiri di dalam Peraturan Mahkamah Agung Republik Indonesia (PERMA) No. 1 Tahun 2008 tentang Prosedur Mediasi di Pengadilan, yang memberikan rumusan bahwa "Mediasi adalah cara penyelesaian sengketa melalui proses perundingan untuk memperoleh kesepakatan para pihak dengan dibantu oleh mediator" (Pasal 1 Angka 7). ${ }^{3}$

Berdasarkan Pasal 1 Angka 7 PERMA No. 1 Tahun 2008 tersebut di atas, maka mediasi merupakan bentuk penyelesaian sengketa melalui suatu perundingan di antara para pihak agar tercapai kesepakatan bersama. Dengan tercapainya kesepakatan bersama di antara para pihak, pada giliran akhirnya pokok persengketaan itu dapat dikatakan selesai atau berakhir oleh karena telah diterima dan telah memuaskan para pihak yang bersengketa.

Penyelesaian sengketa berdasarkan uraian di atas lebih menekankan pada cara atau proses yang digunakan dalam mediasi untuk diserahkan kepada para pihak yang bersengketa, apakah di dalam penyelesaian sengketa ditempuh cara mediasi atau cara lainnya, bergantung pada kesepakatan para pihak dan dalam hal ini fungsi seorang atau lebih selaku perantara (mediator) merupakan hal yang panting yang dapat menjembatani kedua belah pihak yang bersengketa.

Penyelesaian sengketa secara mediasi pada khususnya dan penyelesaian sengketa di luar pengadilan pada umumnya hanya sebatas pada sengketa keperdataan, seperti sengketa hak milik, sengketa tentang hak kewarisan, dan lain-lainnya. Hal itu juga dipertegas oleh Pasal 58 Undang-Undang No. 48 Tahun 2009 tentang Kekuasaan Kehakiman yang telah disebutkan dan dikutip sebelumnya. Hal yang demikian

\footnotetext{
3 Lihat Peraturan Mahkamah Agung Republik Indonesia (PERMA) No. 1 Tahun 2008 tentang Prosedur Mediasi di Pengadilan (Pasal 1 Angka 7).
} 
penting sekali agar dalam persengketaan, ditempuh upaya penyelesaian sengketa secara hukum, bukan secara kekerasan atau cara yang melanggar hukum.

\section{B. Rumusan Masalah}

1. Bagaimana pengaturan hukum tentang penyelesaian sengketa secara mediasi?

2. Bagaimana bentuk putusan penyelesaian sengketa secara mediasi?

\section{Metode Penelitian}

Penelitian ini adalah penelitian hukum normatif (penelitian hukum kepustakaan). Pada penelitian hukum normatif, bahan pustaka merupakan data dasar yang dalam ilmu penelitian digolongkan sebagai data sekunder. ${ }^{4}$

\section{TINJAUAN PUSTAKA}

\section{A. Pengertian Sengketa Dan Penyelesaian Sengketa}

Istilah "Sengketa" (Disputes, bahasa Inggris), seringkali disebut sama dengan "Konflik" (Conflict, bahasa Inggris). Henry Campbell Black menjelaskan arti "Dispute", sebagai: "A conflict of controversy; a conflict of claims or rights; an assentation of a right, claim, or demand on one side, met by contrary claims or allegations on the other. The subject of litigation; the matter for which a suit is brought and upon which issue is joined, and in relation to which jurors are called and witnesses examined". ${ }^{5}$

\section{B. Teori Persengketaan}

Dalam literatur, Teori Persengketaan juga dinamakan dengan Teori Konflik. Pengertian Konflik itu sendiri dirumuskan oleh Dean G. Pruitt dan Jeffrey Z. Rubin bahwa, konflik adalah persepsi mengenai perbedaan kepentingan (perceived

\footnotetext{
4 Soerjono Soekanto dan Sri Mamudji, Penelitian Hukum Normatif, Suatu Tinjauan Singkat, RajaGrafindo Persada, Jakarta, 2001, hlm. 24.

5 Henry Campbell Black, Black's Law Dictionary, West Publishing Co., St. Paul, 1989, p. 424.
}

divergence of interest), atau suatu kepercayaan bahwa aspirasi pihak-pihak yang berkonflik tidak dicapai secara simultan (secara serentak). ${ }^{6}$

Pruitt dan Rubin lebih lanjut melihat konflik dari perbedaan kepentingan atau tidak dicapainya kesepakatan para pihak. Maksud Perbedaan kepentingan adalah berlainannya keperluan atau kebutuhan masing-masing pihak. Misalnya, A. sebagai salah satu ahli waris, menginginkan rumah warisan yang ditinggalkan oleh pewaris dijual, sementara pihak B tidak menginginkan rumah itu dijual karena mengandung nilai-nilai sejarah bagi keluarga. $^{7}$

Perihal Teori Konflik, menurut Salim HS, dapat digolongkan atas:

a. Objek kajiannya;

b. Faktor penyebab terjadinya konflik; dan

c. Strategi dalam penyelesaian konflik. $^{8}$

\section{PEMBAHASAN}

\section{A. Pengaturan Hukum Mengenai}

\section{Penyelesaian Sengketa Secara Mediasi}

Uraian sebelumnya secara jelas menunjukan adanya bentuk penyelesaian sengketa menurut Hukum Indonesia atas dua. Pertama ialah penyelesaian sengketa melalui pengadilan; dan kedua, penyelesaian sengketa di luar pengadilan.

Kedua bentuk penyelesaian kedua merupakan penyelesaian secara hukum, oleh karena diatur menurut hukum. Persamaan antara penyelesaian sengketa melalui pengadilan dan penyelesaian sengketa di luar pengadilan, ialah samasama ditujukan untuk menyelesaikan persengketaan secara hukum. Hal ini berarti, ketika timbul persengketaan atau perselisihan, hanya penyelesaiannya secara hukum yang digunakan, bukan

\footnotetext{
${ }^{6}$ Salim HS, Op Cit, hlm.82

7 Salim HS, Loc Cit.

${ }^{8}$ Ibid, hlm. 85.
} 
penyelesaian secara kekerasan atau cara lainnya yang justru melawan hukum.

Terdapat perbedaan mendasar antara bentuk penyelesaian sengketa melalui pengadilan dan penyelesaian sengketa di luar pengadilan. Perbedaan pertama, ialah kedua bentuk penyelesaian sengketa secara hukum tersebut merupakan aturan hukum (regelen recht). Yang berbeda, ialah tidak semua aturan hukum berisikan hukum sanksi (santie-recht). Kedua penyelesaian sengketa melalui pengadilan memiliki sanksi hukum yang bersifat otonom, sedangkan penyelesaian sengketa di luar pengadilan, sanksinya bersifat heteronom.

Dikatakan bersifat otonom, oleh karena upaya paksa jika putusan pengadilan tidak dilaksanakan oleh para pihak, ada pada lembaga peradilan (Peradilan Umum), antara lainnya melalui aparat penegak hukum, lembaga pemasyarakatan, dan lainlainnya.

Penyelesaian sengketa di luar pengadilan bersifat heteronom dalam penegakan hukumnya, oleh karena putusan arbitrase maupun putusan alternatif penyelesaian sengketa membutuhkan penguatannya lebih lanjut melalui lembaga peradilan. Ada pihak lain yang turut menguatkan kekuatan hukum memaksa dari putusan arbitrase dan alternatif penyelesaian sengketa.

Pembahasan ini lebih dititikberatkan pada penyelesaian sengketa diluar pengadilan, yang secara garis besar dibedakan atas 2 yakni pertama: Penyelesaian sengketa secara arbitrase; dan Kedua, penyelesaian sengketa secara alternatif penyelesaian sengketa, yang masing-masing dibahas lebih lanjut sebagai berikut:

\section{Arbitrase}

Arbitrase (Arbitration, bahasa Inggris) merupakan suatu pengadilan swasta, yang sering juga disebut dengan "pengadilan wasit" sehingga para "arbiter" dalam peradilan arbitrase berfungsi layaknya seorang "wasit" (referee) seumpama wasit dalam pertandingan bola kaki. ${ }^{9}$

Pendapat Munir Fuady yang menyebutkan arbitrase sebagai pengadilan swasta, dan berfungsinya arbiter layaknya sebagai seorang wasit dalam pertandingan sepak bola di atas, sekilas tampak benar, tetapi tidak tepat. Benar, oleh karena Peradilan yang dikenal dalam sistem peradilan di Indonesia dikategorikan sebagai Peradilan Negara. Undang-Undang No. 48 Tahun 2009 tentang Kekuasaan Kehakiman, menentukan bahwa 'Peradilan negara menerapkan dana menegakkan hukum dan keadilan berdasarkan Pancasila" (Pasal 2 ayat (2). Kemudian ditentukan bahwa "Semua peradilan di seluruh wilayah negara Republik Indonesia adalah peradilan negara yang diatur dengan Undang-Undang" (Pasal 2 ayat (3). Hal itu berarti, kedudukan arbitrase sebagai peradilan swasta benar, oleh karena tidak termasuk sebagai bagian dari peradilan negara.

\section{Konsultasi}

Istilah Konsultasi (Consultation, bahasa Inggris), menurut Henry Campbell Black, diartikan sebagai berikut: "Act of consulting or conferring; e.g. patient with doctor; client with lawyer. Deliberation of persons on some subject. A conference between the counsel engage in a case, to discuss its questions or arrange the method of conducting it" ${ }^{10}$

M. Marwan dan Jimmy $P$, menjelaskan arti Konsultasi, sebagai berikut: "Permohonan nasihat atau pendapat untuk menyelesaikan suatu sengketa secara kekeluargaan yang dilakukan oleh para

\footnotetext{
9 Munir Fuady, Arbitrase Nasional (Alternatif Penyelesaian Sengketa Bisnis), Citra Aditya Bakti, Bandung, 2003, hlm. 12.

${ }^{10}$ Henry Campbell Black, Op Cit, p. 286.
} 
pihak yang bersengketa kepada pihak ketiga". ${ }^{11}$

\section{Negosiasi}

Istilah "Negosiasi" dalam terminologi bahasa Inggris disebut dengan "Negotiate" dan "Negotiation". Henry Campbell Black, mengartikan "Negotiation" sebagai "is process of submission and consideration of offers until acceptable offer is made and accepted". ${ }^{12}$

Istilah "Negotiation" diartikan oleh Steven H. Gifis, sebagai berikut: "a method of dispute resolution where either the parties themselves or the representative of each party attempt to settle conflicts without resort to the court; an impartial third party is not involved"13

M. Marwan dan Jimmy $P$, mengartikan Negosiasi sebagai proses tawar-menawar dengan jalan berunding antara para pihak yang bersengketa untuk mencapai kesepakatan bersama. ${ }^{14}$

Berdasarkan beberapa rumusan di atas, negosiasi dan juga Konsultasi merupakan bagian dari penyelesaian sengketa di antara para pihak dengan jalan damai, melalui suatu perundingan. Negosiasi ini pun bukan arbitrase, dan Negosiasi ditempatkan ke dalam bagian dari Alternatif Penyelesaian Sengketa.

\section{Mediasi}

Istilah "Mediasi" dalam bahasa Inggris dinamakan "Mediation" yang diartikan oleh M. Marwan dan Jimmy P. sebagai berikut :

"Negosiasi adalah suatu proses penyelesaian sengketa secara damai yang melibatkan bantuan pihak ketiga untuk memberikan solusi yang dapat diterima pihak-pihak yang bersengketa; pengikutsertaan pihak ketiga dalam

\footnotetext{
${ }^{11}$ M. Marwan dan Jimmy. P, Op Cit, hlm.378.

${ }^{12}$ Henry Campbell Black, Op Cit, p. 934

${ }^{13}$ Steven H Gifis, Op Cit p. 310

${ }^{14}$ M. Marwan dan Jimmy P, Op Cit, hlm 450
}

penyelesaian sengketa antara dua pihak". ${ }^{15}$

Munir Fuady menjelaskan tentang penyelesaian sengketa melalui mediasi, bahwa :

"Yang dimaksud dengan mediasi adalah suatu proses penyelesaian sengketa berupa negosiasi untuk memecahkan masalah melalui pihak luar yang netral dan tidak memihak, yang akan bekerja dengan pihak yang bersengketa untuk membantu menemukan solusi dalam menyelesaikan sengketa tersebut secara memuaskan kedua belah pihak. Pihak ketiga yang netral tersebut disebut dengan mediator" ${ }^{16}$

\section{Konsiliasi}

Istilah konsiliasi dalam bahasa Inggris disebut sebagai "Conciliation", yang oleh Henry Campbell Black, diartikannya sebagai: "The adjustment and settlement of a dispute in a friendly, un-antagonistic manner". ${ }^{17}$

M. Marwan dan Jimmy $P$, mengartikan Konsiliasi sebagai usaha untuk mempertemukan keinginan pihak-pihak bersengketa agar mencapai kesepakatan guna menyelesaikan sengketa dengan kekeluargaan. ${ }^{18}$ Munir Fuady menjelaskan, Konsiliasi mirip dengan mediasi, yakni merupakan suatu proses penyelesaian sengketa berupa negosiasi untuk memecahkan masalah melalui pihak luar yang netral dan tidak memihak yang akan bekerja dengan pihak yang bersengketa untuk membantu menemukan solusi dalam menyelesaikan sengketa tersebut. ${ }^{19}$

\footnotetext{
${ }^{15}$ M. Marwan dan Jimmy.P, Ibid, hlm.426

${ }^{16}$ Munir Fuady, Pengantar Hukum Bisnis. Menata Bisnis Modern di Era Global, Op Cit, hlm. 314

${ }^{17}$ Henry Campbell Black, Op Cit, p. 262

${ }^{18}$ M. Marwan dan Jimmy P, Op Cit, hlm. 376

19 Munir Fuady, Pengantar Hukum Bisnis, Op Cit, hlm. 315
} 


\section{Penilaian Ahli}

Penilaian ahli, merupakan bentuk pendapat ahli yang dapat dipahami dan diterima oleh para pihak yang bersengketa. Dalam Hukum Acara, dikenal sebagai saksi ahli, yakni suatu kesaksian berdasarkan keahlian dari seseorang atau lebih untuk menemukan solusi pada pokok persengketaan.

Penilaian ahli juga dinamakan sebagai keterangan ahli, yang dalam UndangUndang No. 8 tahun 1981 tentang Kitab Hukum Acara Pidana (KUHAP) dirumuskan bahwa "Keterangan ahli adalah keterangan yang diberikan oleh seorang yang memiliki keahlian khusus tentang hal yang diperlukan untuk membuat terang suatu perkara pidana guna kepentingan pemeriksaan" (Pasal 1 Angka 28).

Penilaian ahli sebagai bagian dari cara atau proses penyelesaian sengketa berbeda secara prinsipil dengan keterangan ahli, oleh karena keterangan ahli diberikan atau disampaikan pada suatu sidang pengadilan, sedangkan penilaian ahli dikemukakan atau disampaikan di luar forum pengadilan.

Bentuk penyelesaian sengketa baik melalui pengadilan maupun di luar pengadilan tersebut di atas dikelompokkan sebagai penyelesaian sengketa secara hukum. Terlepas dari penyelesaian sengketa melalui pengadilan, maka penyelesaian sengketa di luar pengadilan baik melalui arbitrase, konsultasi, negosiasi, mediasi, konsiliasi atau penilaian ahli merupakan upaya-upaya yang ditempuh berdasarkan perdamaian. Bukan menggunakan kekerasan, dan perdamaian ditempuh secara musyawarah untuk mufakat.

Objek persengketaan yang menjadi ruang lingkup penyelesaian sengketa melalui arbitrase dan alternatif penyelesaian sengketa hanya terbatas pada objek keperdataan, seperti dalam Perjanjian atau Akad Kredit, Perjanjian atau Akad Pembiayaan Bank Syariah, Perjanjian atau Akad Pembiayaan (multi-finance). Perjanjian atau Akad pendirian Perusahaan patungan (joint Venture) antara perusahaan nasional dengan perusahaan asing, dan lain-lainnya, lazimnya menentukan klausul tertentu manakala kemudian hari timbul persengketaan. Jika tidak ada klausul dan kemudian timbul sengketa, tentunya akan diselesaikan melalui pengadilan (ligitasi).

Arti pentingnya penyelesaian sengketa secara perdamaian yaitu melalui musyawarah untuk mencapai mufakat, adalah ciri khas dari perkara keperdataan, bahwa Hakim berkewajiban mendamaikan para pihak yang bersengketa. Upaya pendamaian oleh Hakim tersebut terjadi ketika persengketaan akan dimulai dengan pemeriksaan Hakim, sehingga menjadi kewajiban Hakim mendamaikan para pihak. M. Yahya Harapan, mengemukakan, kelalaian Hakim mengupayakan perdamaian bagi kedua pihak berperkara akan mengakibatkan batalnya pemeriksaan perkara tersebut demi hukum. ${ }^{20}$

Upaya perdamaian oleh Hakim di atas adalah perdamaian melalui jalur ligitasi, dan perdamaian pula menjadi titik penting dalam penyelesaian sengketa melalui jalur arbitrase dan alternatif penyelesaian sengketa. Ketika pada pihak bersengketa sepakat berdamai, tentunya persengketaan tersebut dapat terselesaikan oleh karena ada niat atau itikad baik dari pada pihak bersangkutan.

\section{B. Bentuk Putusan Penyelesaian Sengketa Melalui Mediasi}

Terlebih dahulu penulis ingatkan, sebelumnya dikemukakan sejumlah peraturan perundangan yang dengan tegas mengatur Penyelesaian Sengketa, misalnya dalam Undang-Undang No. 8 Tahun 1999 tentang Perlindungan Konsumen (Bab $\mathrm{X}$ di bawah judul Penyelesaian Sengketa, Undang-Undang No. 25 Tahun 2007

\footnotetext{
${ }^{20}$ M.Yahya Harahap, Op Cit, hlm. 239
} 
tentang Penanaman Modal, (Bab XV), di bawah judul Penyelesaian Sengketa, Undang-Undang no. 21 Tahun 2008 tentang Perbankan Syariah (Bab IX) di bawah judul Penyelesaian Sengketa, dan UndangUndang No. 48 Tahun 2009 tentang Kekuasaan Kehakiman (Bab XII) di bawah judul Penyelesaian Sengketa di Luar Pengadilan.

Sejumlah peraturan perundangan di atas dengan tegas mengatur penyelesaian sengketa, baik melalui jalur ligitasi maupun non-ligitasi, akan tetapi pada dasarnya dalam setiap hak-hak keperdataan menyangkut hak dan kewajiban yang timbul dari suatu hubungan hukum, masih ada landasan atau dasar hukumnya yang menjamin dan mengatur pemenuhan hak dan kewajiban manakala terjadi sengketa, yakni dalam Hukum Perdata dikenal asas Konsensual (Pasal 1338 KUH. Perdata), bahwa semua persetujuan yang dibuat secara sah dan berlaku sebagai undangundang bagi mereka yang membuatnya."

Hubungan hukum antara pihak yang satu dengan pihak lainnya selain berintikan pada sejumlah hak, juga berintikan pada sejumlah kewajiban yang bersifat timbal balik. Hukum Perdata menentukannya dalam konteks kebebasan membuat perjanjian oleh karena Hukum Perjanjian dalam Buku III KUH. Perdata lazim dinamakan sistem terbuka. ${ }^{21}$

Jika dalam suatu Perjanjian, Kontrak, atau Akad bisnis tidak diatur cara atau mekanisme penyelesaian sengketa, tidaklah berarti hukum tidak menjangkaunya, oleh karena hubungan-hubungan hukum menurut Hukum Perjanjian ( Hukum Bisnis) tidak hanya bersumber dari undangundang, melainkan juga bersumber di luar undang-undang.

Penyelesaian sengketa yang secara garis besar dibedakan dalam penyelesaian

\footnotetext{
${ }^{21}$ Subekti, Pokok-Pokok Hukum Perdata, Op Cit, hlm. 128
}

sengketa melalui pengadilan dan penyelesaian sengketa di luar pengadilan. Tentang penyelesaian sengketa di luar pengadilan pun masih dibedakan secara garis besar atas, penyelesaian sengketa melalui arbitrase, dan penyelesaian sengketa dengan cara-cara atau prosesproses tertentu, yakni: Konsultasi, Negosiasi, Mediasi, Konsiliasi, dan/atau penilaian ahli.

Pada hakikatnya, bentuk-bentuk penyelesaian sengketa di luar pengadilan berlandaskan pada perundingan, oleh karena dalam Arbitrase, Konsultasi, Negosiasi, Mediasi, Konsiliasi, dan penilaian ahli, bertolak dari kemampuan merundingkan berbagai aspek untuk mendapatkan solusi sebagai pemecahan masalahnya yang dapat memuaskan dan diterima oleh para pihak.

Dengan mengkaji Undang-Undang No. 30 tahun 1999 yang menjadi dasar dan bahan rujukan berbagai peraturan perundang-undangan jika suatu penyelesaian sengketa diselesaikan melalui arbitrase, atau dengan cara-cara lainnya, sebenarnya Undang-Undang No. 30 Tahun 1999 lebih berat sebelah mengatur tentang arbitrase, dan kurang sekali mengatur tentang alternatif penyelesaian sengketa.

Dari sebanyak 81 Pasal Undang-Undang No. 30 Tahun 1999, hanya Pasal 6 (satu pasal) saja yang mengatur tentang alternatif penyelesaian sengketa, sementara arbitrase banyak menggunakan cara-cara Konsultasi, Negosiasi, Mediasi, Konsiliasi, dan penilaian ahli.

Pembahasan menarik dan penting mengenai bentuk putusan mediasi ialah, dalam sistem Hukum Indonesia dikenal mediasi melalui pengadilan; dan mediasi di luar pengadilan, yang masing-masing dibahas sebagai berikut.

Mediasi di pengadilan diatur dengan Undang-Undang No. 48 Tahun 2009 tentang Kekuasaan Kehakiman, bahwa "Ketentuan sebagaimana dimaksud pada 
ayat (1) tidak menutup usaha penyelesaian perkara perdata secara perdamaian" (Pasal 10 ayat (2). Sedangkan mediasi di luar pengadilan, dalam Undang-Undang No. 48 Tahun 2009 tentang Kekuasaan Kehakiman, diatur pada Bab XII dari Pasal 58 sampai dengan Pasal 61. Empat pasal ini merujuk pada Undang-Undang No. 30 Tahun 1999 tentang Arbitrase dan Alternatif Penyelesaian Sengketa.

Menurut Undang-Undang No. 48 Tahun 2009, mediasi melalui pengadilan diatur lebih lanjut dalam PERMA No. 1 Tahun 2008 tentang Prosedur Mediasi di Pengadilan, yang ditetapkan pada tanggal 31 Juli 2008. PERMA no. 1 Tahun 2008 yang terdiri atas VIII Bab dan 27 Pasal, tidak sama sekali merujuk dan tidak pula mengacu kepada Undang-Undang No. 30 Tahun 1999 sebagaimana yang tidak ditemukannya Undang-Undang No. 30 Tahun 1999 dalam Konsiderans "Mengingat" PERMA yang dimaksudkan itu.

Bahan pertimbangan, sesuai Konsiderans "Menimbang" dari PERMA No.1 Tahun 2008 berbunyi, bahwa mediasi merupakan salah satu proses penyelesaian sengketa yang lebih cepat dan murah, serta dapat memberikan akses yang lebih besar kepada para pihak menemukan penyelesaian yang memuaskan dan memenuhi rasa keadilan.

a. Bahwa pengintegrasian mediasi ke dalam proses beracara di pengadilan dapat menjadi salah satu instrumen efektif mengatasi masalah pemupukan perkara di pengadilan serta memperkuat dan memaksimalkan fungsi lembaga pengadilan dalam penyelesaian sengketa di samping proses pengadilan yang bersifat memutus (adjukatif).

b. Bahwa hukum acara yang berlaku, baik Pasal 130 HIR maupun Pasal 154 Rag, mendorong para pihak untuk menempuh proses perdamaian yang dapat diintensifkan dengan cara mengintegrasikan proses mediasi ke dalam prosedur berperkara di Pengadilan Negeri.

c. Bahwa sambil menunggu peraturan perundang-undangan dan memperhatikan wewenang Mahkamah Agung dalam mengatur acara peradilan yang belum cukup diatur oleh peraturan perundang-undangan, maka demi kepastian, ketertiban, dan kelancaran dalam proses mendamaikan para pihak untuk menyelesaikan suatu sengketa perdata dipandang perlu menetapkan suatu Peraturan Mahkamah Agung.

PERMA No. 1 Tahun 2008 mengatur ruang lingkup dan kekuatan berlakunya PERMA, pada Pasal 2 ayat-ayatnya, sebagai berikut:

1. Peraturan Mahkamah Agung ini hanya berlaku untuk mediasi yang terkait dengan proses berperkara di Pengadilan.

2. Setiap Hakim, mediator, dan para pihak wajib mengikuti prosedur penyelesaian sengketa melalui mediasi yang diatur dalam Peraturan ini.

3. Tidak menempuh prosedur mediasi berdasarkan Peraturan ini merupakan pelanggaran terhadap ketentuan Pasal 130 HIR dan/atau Pasal 154 RBg yang mengakibatkan putusan batal demi hukum.

4. Hakim dalam pertimbangan putusan perkara wajib menyebutkan bahwa perkara yang bersangkutan telah diupayakan perdamaian melalui mediasi dengan menyebutkan nama mediator untuk perkara yang bersangkutan".

Ketentuan Pasal 2 ayat (1) PERMA di atas hanya berlaku bagi mediasi yang terkait dengan proses berperkara di pengadilan. Hal tersebut secara tegas menyatakan bahwa mediasi yang dimaksudkan adalah mediasi melalui jalur ligitasi, dan mediasi yang dimaksud itu adalah bentuk perdamaian (dading). Menurut A. Ridwan Halim, diterangkan bahwa: 
“Dading atau perdamaian antarpihak itu tercapai atas prakarsa para pihak, mengingat secara psikologis tentunya dapat dimengerti bila setiap pihak yang beritikad baik akan tetap berusaha mencari penyelesaian perkara sedapat mungkin melalui jalan damai. Tetapi, disamping itu, secara yuridis-formal dalam Pasal 130 ayat (1) HIR ditegaskan bahwa bila kedua belah pihak datang di persidangan, maka Hakim pengadilan negeri yang bersangkutan wajib mencoba dengan perantaraan Ketua Pengadilan Negeri tersebut untuk mendamaikan para pihak". ${ }^{22}$

PERMA no. 1 Tahun 2008 mengatur tahap Pra-Mediasi, dan Tahap-Tahap Proses Mediasi. Pada tahap Pra-mediasi, ditentukan pada Pasal 7 bahwa "Kewajiban Hakim Pemeriksa Perkara dan Kuasa Hukum:

1. Pada hari Sidang yang telah ditentukan yang dihadiri kedua pihak, Hakim mewajibkan para pihak untuk menempuh mediasi.

2. Ketidakhadiran pihak turut tergugat tidak menghalangi pelaksanaan mediasi.

3. Hakim, melalui kuasa hukum atau langsung kepada para pihak, mendorong para pihak untuk berperan langsung atau aktif dalam proses mediasi.

4. Kuasa hukum para pihak berkewajiban mendorong para pihak sendiri berperan langsung atau aktif dalam proses mediasi.

5. Hakim wajib menunda proses persidangan perkara untuk memberikan kesempatan kepada para pihak menempuh proses mediasi.

6. Hakim wajib menjelaskan prosedur mediasi dalam PERMA ini kepada para pihak yang bersengketa.
PERMA dimaksud juga mengatur tahaptahap proses mediasi, yang dirinci atas Penyerahan Resume Perkara dan Lama Waktu Proses Mediasi (Pasal 13). Kewenangan Mediator Menyatakan Mediasi Gagal (Pasal 14), Tugas-Tugas Mediator (Pasal 15), dan Keterlibatan Ahli (Pasal 16).

Prosedur lebih lanjut terjadi jika mencapai kesepakatan, yang dalam PERMA ditentukan pada Pasal 17 ayat-ayatnya, sebagai berikut:

1. Jika mediasi menghasilkan kesepakatan perdamaian, para pihak dengan bantuan mediator wajib merumuskan secara tertulis kesepakatan yang dicapai dan ditandatangani oleh para pihak dan mediator.

2. Jika dalam proses mediasi para pihak diwakili oleh kuasa hukum, para pihak wajib menyatakan secara tertulis persetujuan atas kesepakatan yang dicapai.

3. Sebelum para pihak menandatangani kesepakatan, mediator memeriksa materi kesepakatan perdamaian untuk menghindari ada kesepakatan yang bertentangan dengan hukum atau tidak dapat dilaksanakan atau yang memuat itikad tidak baik.

4. Para pihak wajib menghadap kembali kepada hakim pada hari sidang yang telah ditentukan untuk memberitahukan kesepakatan perdamaian.

5. Para pihak dapat mengajukan kesepakatan perdamaian kepada hakim untuk dikuatkan dalam bentuk akta perdamaian.

6. Jika para pihak tidak menghendaki kesepakatan perdamaian dikuatkan dalam bentuk akta perdamaian, kesepakatan perdamaian harus memuat klausula pencabutan gugatan dan/atau klausula yang menyatakan perkara telah selesai.

\footnotetext{
${ }^{22}$ A. Ridwan Halim, Op Cit, hlm. 155
} 
Ketentuan di atas merupakan wujud atau bentuk kesepakatan yang dihasilkan melalui mediasi di pengadilan, yang tentunya berbeda dari mediasi sebagai bentuk penyelesaian sengketa di luar pengadilan yang mengacu kepada UndangUndang No. 30 tahun 1999 tentang Arbitrase dan Alternatif Penyelesaian Sengketa.

Baik dalam BANI maupun dalam BASYARNAS diatur pokoknya dalam lingkup arbitrase, dan pada dasarnya kurang menjangkau alternatif penyelesaian sengketa, namun pada hakikatnya, baik dalam arbitrase maupun dalam alternatif penyelesaian sengketa, kedudukan dan peran mediasi sangat penting artinya.

Arbitrase juga bertumpu pada kehendak bersama para pihak dan/atau dengan pihak ketiga untuk mencari jalan damai yang dapat memuaskan pada pihak. Konsultasi, Negosiasi, Mediasi, Konsiliasi maupun Pendapat ahli, juga bertumpu pada kehendak bersama yang menghendaki tercapainya suatu kata sepakat, bersama untuk mengatasi persengketaan yang dihadapi dengan jalan damai.

Penyelesaian sengketa Perbankan Syariah melalui BASYARNAS adalah mengacu pada Undang-Undang No. 30 Tahun 1999, akan tetapi terdapat permasalahan dalam hal eksekusinya. Salah satu kelemahan arbitrase dan alternatif penyelesaian sengketa adalah dalam hal eksekusi, oleh karena arbitrase dan alternatif penyelesaian sengketa tidak memiliki kekuatan memaksa, sehingga putusan arbitrase maupun alternatif penyelesaian sengketa membutuhkan penguatannya lebih lanjut, baik pendaftarannya ke Pengadilan Negeri, maupun aspek pemaksa Pengadilan Negeri yang bersifat otonom.

Kekuatan memaksa arbitrase dan alternatif penyelesaian sengketa bersifat dari luar (heteronom), yakni dari Pengadilan Negeri agar dapat dilaksanakannya putusan arbitrase maupun mediasi yang telah dicapai.

Terdapat permasalahan dalam arbitrase dan alternatif penyelesaian sengketa dalam praktiknya, oleh karena putusannya bersifat final. Padahal, sistem peradilan masih membuka peluang adanya upaya banding, kasasi bahkan Peninjauan Kembali (PK).

Klausul Akad Pembiayaan pada Bank Syariah juga menentukan ketentuan yang serupa, misalnya, jika musyawarah dan mufakat tidak tercapai, sengketa yang dimaksud diselesaikan melalui Pengadilan Negeri, dan putusannya bersifat final dan mempunyai kekuatan hukum.

Mediasi pada dasarnya adalah musyawarah dan mufakat, yakni sebagai suatu cara atau proses selain cara atau proses lainnya baik melalui arbitrase, negosiasi, konsiliasi, dan lain-lainnya. Jika secara mediasi terdapat kata sepakat, dan dituangkan dalam suatu akta perdamaian, sebenarnya akta perdamaian ini adalah produk hukum dan memiliki kekuatan mengikat sebagaimana karakteristik asas konsensual menurut Pasal $1338 \mathrm{KUH}$. Perdata. Dengan demikian, kesepakatan yang dibuat secara sah, berlaku sebagai undang-undang bagi para pihak yang bersengketa, oleh karena dalam akta perdamaian tersebut para pihak telah mencapai kesepakatan dan sama-sama merasa puas, adil, dan menyelesaikan persengketaan yang ada di antara mereka.

Putusan mediasi, sedikit banyak tergantung dari kemampuan dan kapasitas serta kredibilitas seorang sebagai mediator. Dalam kasus atau sengketa/konflik antara warga (konflik horizontal) seperti kasus kekerasan di Poso, Ambon, dan lainlainnya, kemampuan Jusuf Kalla sebagai mediator, teruji dan dapat meredam persengketaan di daerah-daerah yang bersangkutan.

Mediator memegang peranan penting dalam menjembatani para pihak, yang ketika terjadi sengketa, telah ada jarak 
(gap) antara para pihak, seperti saling bermusuhan, saling mencemarkan nama baik, terjadi tidak saling percaya, dan lainlainnya sebagai efek dan ekses psikologis karena terjadi suatu persengketaan itu.

Penyelesaian sengketa sekaligus pemecahan masalah sengketa tersebut secara mediasi yang dimaksudkan di sini, ialah mediasi di luar pengadilan (nonligitasi), yang memberikan peluang untuk dicapainya kata sepakat bersama diantara para pihak. Mediasi yang demikian, tidak selamanya dalam tataran pendekatan formal, tetapi juga dapat melalui tataran non-formal, oleh karena hasil akhirnya yang hendak dicapai.

Mediasi itu sendiri hanya suatu cara, suatu proses, serta bukanlah suatu tujuan. Mediasi sebagaimana halnya arbitrase dan alternatif penyelesaian sengketa yang lainnya, sedikit banyak merujuk, mengikuti, dan mendasarkan pada cara atau proses menurut penyelesaian sengketa secara arbitrase, oleh karena Undang-Undang No. 30 Tahun 1999, tidak dengan spesifik atau khusus mengatur bagaimana prosedur atau mekanisme dalam mediasi.

Dengan demikian, penyelesaian sengketa melalui mediasi tidaklah bersifat kaku, resmi atau formal, oleh karena ketika tanpa seorang perantara selaku mediator, terdapat kesepakatan di antara para pihak yang bersengketa untuk menyelesaikan sengketanya, maka kesepakatan itu adalah bentuk putusan yang mengikat bagi para pihak yang bersengketa. Kekuatan mengikatnya kata sepakat tersebut jika melalui pendekatan formal, yakni melibatkan mediator, maka kata sepakat tersebut harus pula didaftarkan di Pengadilan, dan dengan demikian, penyelesaian sengketa baik melalui arbitrase maupun melalui alternatif penyelesaian sengketa, tidak terlepas dari peran dan tanggungjawab lembaga pengadilan, yang dalam hal ini adalah Pengadilan Negeri.
Di sini pula membuktikan penyelesaian sengketa tersebut sebagai penyelesaian sengketa secara hukum, meskipun terdapat dua bentuk jalurnya, yakni secara ligitasi dan secara non-ligitasi.

Kesepakatan yang dicapai dalam penyelesaian sengketa secara arbitrase membutuhkan pendaftarannya sebagai penguatan ke Pengadilan, dan hal yang sama juga dapat ditempuh dalam penyelesaian sengketa melalui mediasi, yakni akta perdamaian atau akta kesepakatan juga membutuhkan pendaftaran sekaligus penguatannya di Pengadilan.

Ketika sampai adanya campur tangan di Pengadilan, yang di dalam hal ini adalah Pengadilan Negeri, sebenarnya penyelesaian sengketa secara arbitrase dan alternatif penyelesaian sengketa telah menjadi bagian dari ranah Peradilan Umum.

\section{PENUTUP}

\section{A. Kesimpulan}

1. Bentuk penyelesaian sengketa menurut hukum terdiri atas penyelesaian sengketa melalui pengadilan (Legitasi), dan penyelesaian sengketa diluar pengadilan (non-legitasi). Sedangkan penyelesaian sengketa diluar pengadilan dibagi atas dua bagian besar yaitu melalui arbitrase, dan melalui alternatif penyelesaian sengketa yang meliputi cara-cara: Konsultasi, Negosiasi, Mediasi, Konsolidasi, dan penilaian ahli.

2. Mediasi adalah cara bermusyawarah dan bermufakat, untuk mencapai kesepakatan bagi para pihak bersengketa, melalui perantaraan seorang selaku mediator. Jika kata sepakat dicapai maka dibutuhkan penguatan dalam bentuk akta perdamaian sebagai putusan mediasi yang didaftarkan dan dikuatkan oleh Pengadilan Negeri. Tercapainya 
kesepakatan melalui mediasi, dengan sendirinya persengketaan selesai atau berakhir.

\section{B. Saran}

Penyelesaian sengketa melalui mediasi dan alternatif penyelesaian sengketa untuk pertama kalinya diakui dan diatur dalam Undang-undang No. 48 Tahun 2009 tentang Kekuasaan Kehakiman (Bab XII) sebatas persengketaan keperdataan, membutuhkan perubahan terhadap Undang-undang No. 30 Tahun 1999 yang lebih banyak mengatur arbitrase dibandingkan alternatif penyelesaian sengketa. Perubahan dimaksud hendaknya sejalan pula dengan perubahan dalam Hukum Acara Perdata.

Perlunya penyelesaian sengketa melalui mediasi untuk mencapai kesepakatan bersama diantara para pihak, selain menutup kemungkinan menumpuknya berkas perkara di pengadilan, juga dapat dijadikan sarana dalam memecahkan persengketaan secara damai yang diterima dan mengikat para pihak yang bersengketa.

\section{DAFTAR PUSTAKA}

Adolf, Huala, Arbitrase Komersial Internasional, Rajawali Pers, Jakarta, 1991.

Dasar-dasar Hukum Kontrak internasional, Refika Aditama, Bandung, 2007.

Amirizal, Hukum Bisnis. Risala Teori dan Praktik, Djambatan , Jakarta, 1999.

Anshori, Abdul Ghofar, Peradilan Agama di indonesia Pasca UU No. 3 Tahun 2006 (Sejarah, Kedudukan, dan Kewenangan), UII Press, Yogyakarta, 2007.

Badrulzaman, Mariam Darus, Aneka Hukum Bisnis, Alumni, Bandung, 1994.

Black, Henry Campbell, Black's Law Dictonary, West Publishing Co., St. Paul, 1979.

Basan, Sjachran, Hukum Acara Pengadilan Dalam Lingkungan Peradilan
Administrasi, Rajawali Pers, Jakarta, 1992.

Basir, Cik, Penyelesaian Sengketa Perbankan Syariah di Bank Syariah, Sinar Grafika, Jakarta, 2012.

Fuady, Munir, Arbitrase Nasional (Alternatif Penyelesaian Sengketa Bisnis), Citra Aditia Bakti, Bandung, 2003.

Pengantar Hukum Bisnis, Menata Bisnis Modern di Era Global, Citra Aditya Bakti, Bandung, 2005.

Gifis, Steven H, Law Dictonary, Baroon's Educational Series, New York, 1984.

Hadimulyo, Mempertimbangkan ADR, Kajian Alternatif Penyelesaian Sengketa di Luar Peradilan, EISAM, Jakarta, 1997.

Halim, A. Ridwan, Hukum Acara Perdata Dalam Tanya-Jawab, Ghalia Indonesia, Jakarta, 2005.

Harahap, M. Yahya, Arbitrase, Sinar Grafika, Jakarta, 2001.

HS, Salim, Perkembangan Teori Dalam Ilmu Hukum, Raja Grafindo Persada, Jakarta, 2010.

Khairandy, Ridwan, Kompetensi Absolut Dalam Penyelesaian Sengketa di Perusahaan Joint Venture, dimuat dalam Jurnal Hukum Bisnis, Volume 26, No. 4 Tahun 2007.

Kusumaatmaja, Mochtar, Konsep-Konsep Hukum Dalam Pembangunan, Alumni, Bandung, 2006.

Marwan, M , dan Jimmy P, Kamus Hukum, Reality Publisher, Surabaya, 2009.

Soekanto, Soerjono, dan Mamudji, Sri, Penelitian Hukum Normatif. Suatu Tinjauan Singkat, RajaGrafindo Persada, Jakarta, 2001.

Subekti, Pokok-pokok Hukum Perdata, Intermasa, Jakarta, 1989. Hukum Pembuktian, Pradnya Paramita, Jakarta, 2008.

\section{Peraturan Perundang-Undangan}

Undang-Undang No. 8 Tahun 1999 tentang Perlindungan Konsumen. 
Undang- Undang No. 30 Tahun 1999 tentang Arbitrase dan Alternatif Penyelesaian Sengketa.

Undang-Undang No. 25 Tahun 2007 Tentang Penanaman Modal.

Undang-Undang No. 21 Tahun 2008 tentang Perbankan Syariah.

Undang-Undang No. 48 Tahun 2009 tentang Kekuasaan Kehakiman.

Undang-Undang No. 49 Tahun 2009 tentang Perubahan Kedua Atas UndangUndang No. 2. Tahun1986 tentang Peradilan Umum.

Undang-Undang No. 50 Tahun 2009 tentang Perubahan Kedua Atas UndangUndang No. 7 Tahun 1989 Tentang Peradilan Agama.

Peraturan Mahkamah Agung (PERMA RI) No. 1 Tahun 2008 tentang Prosedur Mediasi di Pengadilan.

Surat edaran Ketua Mahkamah Agung (SEMA) No. 08 Tahun 2008 tentang Eksekusi Putusan Badan Arbitrase Syariah.

Surat Keputusan Dewan Pimpinan Majelis Ulama Indonesia (MUI) No. Kep09/MUI/XII/2003 tentang Badan Arbitrase Syariah Nasional. 